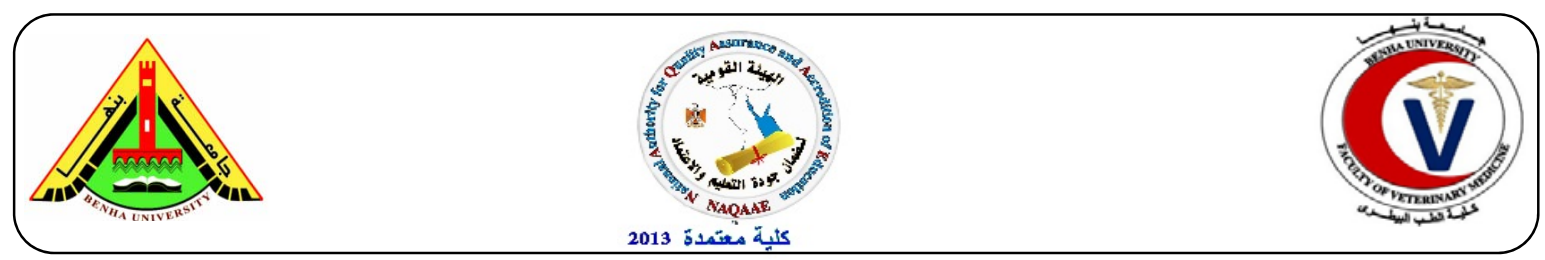

\title{
Efficacy of locally prepared Salmonella Kentucky vaccine in chicken
}

\author{
Nourhan N. Mohammed ${ }^{1}$; Sadek, M.A. ${ }^{2}$; Wafaa R. Abdel Aziz²; Soliman, E.M.'; Eman, S.A. \\ Zaki $^{2}$ and Ibrahim, H.M. ${ }^{2}$ \\ ${ }^{1}$ Central Laboratory for Evaluation of Veterinary Biologics, Abbasia, Cairo. ${ }^{2}$ Veterinary Serum and \\ Vaccine Research Institute, Abbasia, Cairo
}

\begin{abstract}
A B S T R A C T
In the present study, efficacy of a locally prepared Salmonella Kentucky killed vaccine had been studied. A total of 120, two weeks old specific pathogen free (SPF) chicks were divided into two groups; 60 chicks each. First group was vaccinated with the prepared vaccine at the age of two weeks and boostered at four weeks, the second group was kept unvaccinated as a control group. The two groups were challenged orally with $1 \mathrm{ml}$ of Salmonella Kentucky $\left(5 \times 10^{7} \mathrm{CFU} / \mathrm{ml}\right), 3$ weeks post boostering of the vaccine. The degree of protection was assessed according to the severity of the clinical signs, the mortality and fecal shedding of the challenged organisms. Blood samples were collected weekly after first vaccination till fourth week after challenge and humoral immune response was measured against Salmonella strains using ELISA and microagglutination test. The prepared vaccine induced $80 \%$ protection rate in challenge test with reduced fecal shedding.
\end{abstract}

KEYWORDS: Aluminum hydroxide gel, vaccine, Salmonella Kentucky, chicken.

(http://www.bvmj.bu.edu.eg)

(BVMJ-29(2): 153-160, 2015)

\section{INTRODUCTION}

$\mathrm{S}$ almonella is a member of Enterobacteriaceae consists of two species - Salmonella enterica and Salmonella bongori. Salmonella enterica consists of six subspecies (ssp.) under which there are 2500 serovars (Grimont and Weill, 2007) that can produce diseases in mammals including animals and humans, and a good number of them can be harboured by poultry without showing any clinical signs (Gast, 2007). Salmonellae are among the most important agents of foodborne infections. Poultry and poultry products are the major sources of salmonella contaminated food products that cause human salmonellosis (Tietjen and Fungdy, 1995). The United States centers for disease control and prevention (CDC) reported that human cases of salmonellosis were found to be caused by some sero types of which $S$. Enteritidis, $S$. Typhimurium and $S$. Kentucky were included in the report and reported to be wild spread (Task Force on Zoonoses Data Collection, TFZDC, 2007).
Since 2002, S. enterica serovar Kentucky has shown an increase in several countries with the concurrent emergence of multidrug-resistant isolates. The spread of such strains in the environment poses a major public health problem (Turki et al., 2012). Salmonella Kentucky isolated in Egypt showed high degree of antibiotic resistance especially toward ciprofloxacin which considered the drug of choice for Salmonella treatment. (Nourhan et al., 2014). Control of Salmonella infections in poultry is posing itself as one of the difficult problems not only for those who are concerned with poultry industry, but also for public health hazard because of the fact that most of the serovars of Salmonellae that poultry harbour can act as potential pathogens for man (Van Duijkeren et al., 2004). Many researchers all over the world have been trying to control and eradicate salmonellosis in poultry by vaccination. Live attenuated Salmonella vaccines may be hazardous because the residual virulence 
due to insufficient attenuation (Arnon et al., 1983). Inactivated vaccines for the prevention of avian Salmonellosis have been reported by several authors (Barbour et al., 1993; Liu et al., 2001 and ElEnbaawy et al., 2013) which provided good protection with decrease or absence the residual virulence. So that, the following study was conducted to prepare and evaluate a killed vaccine of a locally isolated Salmonella Kentucky in specific pathogen free chicks by ELISA, Microagglutination test and challenge test.

\section{MATERIAL AND METHODS}

\subsection{Bacterial strain}

Local field isolate of Salmonella Kentucky (S.K.) was kindly obtained from Animal Health Research Institute, Dokki, Giza and then identified according to Hofstad et al., 1997.

\subsection{Experimental birds:}

A total number of 140 specific pathogens free (SPF) chicks of 1-day old was obtained from SPF poultry farm at Koom Osheem Fayuom province, Egypt. They were housed in batteries with the network floor. All birds were ascertained first to be free from Salmonella. They were fed on free balanced ration.

\subsection{Vaccine preparation (Charles et al., 1994):}

Salmonella Kentucky was grown on soya agar in Roux bottle at $37^{\circ} \mathrm{C}$ for 48 hours. The colonies were harvested with normal saline and the bacterial suspension was prepared and adjusted to contain $10^{10}$ colony forming unit / $\mathrm{ml}$ using total colony count technique. The inactivating agent (formalin solution 37\%) was added to bacterial suspension in final concentration of $0.3 \%$. The inactivation was carried out under stirring for $24 \mathrm{hrs}$ at $24^{\circ} \mathrm{C}$ to complete the inactivation process. The inactivated cultures were neutralized with sodium meta-bisulfite then stored at temperature of $5-7^{\circ} \mathrm{C}$, and then $20 \%$ of aluminum hydroxide gel was added as an adjuvant.

\subsection{Quality control on the prepared vaccine}

\subsubsection{Purity Test}

Testing of the prepared vaccine to ensure that it is free from any contamination as aerobic, anaerobic bacteria and fungi (OIE Terrestrial Manual 2008).

\subsubsection{Safety Test (OIE Terrestrial Manual 2008).}

Safety of the prepared vaccine was monitored through injection of double field dose $(1 \mathrm{ml})$ of the vaccine subcutaneously in each of 20 SPF chicks. The chicks were observed daily for two weeks for any signs of local reactions, clinical signs or deaths.

\subsubsection{Potency test:}

The humeral immune response of the vaccinated chicks against Salmonella Kentucky was evaluated by ELISA test and Microagglutination test.

\subsubsection{Efficacy test:}

\subsubsection{Challenge test:}

Via challenging of the vaccinated chicks 3 weeks post boostering dose by a dose of 1 $\mathrm{ml}$ Salmonella Kentucky broth culture containing $5 \times 10^{7}$ virulent organisms (OIE, 2012)

\subsubsection{Fecal shedding:}

Shedding of Salmonella Kentucky was detected in fecal samples collected from challenged vaccinated and non-vaccinated chicks up to 4 weeks post challenge.

\subsection{Experimental design:}

Two groups of SPF chicks each of 60 chicks were reared separately; the first group of chicks was injected with $0.5 \mathrm{ml}$ of the prepared vaccine subcutaneously at two weeks of age then boostered with another same dose after two weeks. The second group was used as a control (nonvaccinated). The two groups were challenged three weeks after the booster dose by oral administration of $1 \mathrm{ml}$ from Salmonella Kentucky virulent strain suspension containing $5 \times 10^{7} \mathrm{CFU} / \mathrm{ml}$ (OIE, 
2012). The inoculated chickens were observed for one month. The degree of protection was assessed according to the severity of the clinical signs, the mortality and the recovery of the challenge organisms from fecal samples. Blood samples (2$5 \mathrm{ml} /$ bird) were collected from wing vein before immunization, weekly after each vaccination and post challenge for three weeks (once/week) to measure and evaluate the developed immune response to Salmonella Kentucky. Fecal samples were collected before the start of the experiment and after challenge for one month (once/week) using sterile swabs which were inoculated into tetrathionate broth from all chickens including the vaccinated and the control ones and examined bacteriologically for shedding of Salmonellae according to Hofstad et al. 1997 and Cruickshank et al. 1975.

\subsection{Evaluation of humoral immune} response against Salmonella Kentucky in the vaccinated chicks:

The developed humoral immune response against Salmonella Kentucky in the vaccinated chickens was measured in the sera using ELISA according to Haider et al. 2007 and micro-agglutination test according to Brown et al. (1981)

Calculation of the antibody titers was performed in ELISA; the antibody titer was calculated in relation to $\mathrm{S} / \mathrm{P}$ ratio according to the following formulae:

$\mathrm{S} / \mathrm{P}$ ratio $=\frac{\text { Sample mean }- \text { Negative control }}{\text { Positive control }- \text { Negative control }}$

Calculation of Antibody Titer: $\log ^{10}$ Titer=1.13Log ${ }^{(\mathrm{SP})}+3.156$.

AntiLog= Antibody titer

The antibody titer in MAT was expressed as Geometric Mean Titer (GMT).

\section{RESULTS}

\subsection{Results of quality control on the prepared vaccines:}

The prepared vaccine proved to be pure, sterile, safe and free from adverse side effects on chicken's productivity and body weight gain.

\subsection{Protective Efficacy of the vaccines:}

The protection rate of the prepared vaccine was $80 \%$ after 4 weeks post challenge (Table 1).

\subsection{Fecal Shedding of salmonellae from challenged broiler chickens:}

The re-isolation rates of salmonellae from chickens vaccinated with the inactivated Salmonella Kentucky vaccine in the $1^{\text {st }}, 2^{\text {nd }}$ and $3^{\text {rd }}$ weeks post challenge were $20.75 \%$, $12.5 \%$ and $8.33 \%$, respectively while in the $4^{\text {th }}$ week the fecal shedding disappeared. Regarding the control unvaccinated birds, the re-isolation rates were $70.8 \%, 50 \%$, $25 \%$ and $16.66 \%$ in the $1^{\text {st }}, 2^{\text {nd }}, 3^{\text {rd }}$ and $4^{\text {th }}$ weeks post challenge, respectively (Table 2). Chickens in vaccinated group suffered from mild white diarrhea, with slight lesions of enteritis. Chickens in the control group were suffered from profuse white watery diarrhea, depression and the birds were reluctant to move. The PM lesions included enteritis, cecal core, swollen liver, spleen and gallbladder with small necrotic foci in the liver, in some cases the pericardium was turbid and covered with yellowish white materials.

\subsection{Re-isolation of Salmonella Kentucky from survived chickens after challenge:}

Data presented in Table (3) showed that Salmonella Kentucky could only be reisolated from ceca $(18.75 \%)$ of the vaccinated group while it was re-isolated from heart blood, liver, spleen and ceca in $75 \%, \quad 58.33 \%, \quad 58.33 \%$ and $75 \%$, respectively for control non vaccinated group.

\subsection{Evaluation of humoral immune responses in the vaccinated chickens:}

\subsubsection{ELISA Test:}

The ELISA antibody titer in sera of vaccinated chicks was increased from 162.8 pre-vaccination level to 189.2 at the $1^{\text {st }}$ week and 659.5 at the $2^{\text {nd }}$ week after the primary immunization while post boostering it increased to1085.2 at the $1^{\text {st }}$ week, 1130.2 at the $2^{\text {nd }}$ week and 2234.1 at 
the $3^{\text {rd }}$ week post boostering. After challenge a decrease occurred at the $1^{\text {st }}$ week as it reached 1630 then increased to 2222.3 at the $2^{\text {nd }}$ week and 2249.6 at the $3^{\text {rd }}$ week and 2272.1 at the $4^{\text {th }}$ week post challenge (Table 4). On the other hand, The ELISA antibody titer in sera of unvaccinated chicks was 155.3. Moreover, an abrupt increase of antibody titer was recorded, where the antibody titer was $891.24^{\text {th }}$ week of challenge (Table 4).

\subsubsection{Microagglutination Test:}

The antibody titer in sera of vaccinated chicks was increased from zero prevaccination level to 43 at the $1^{\text {st }}$ week and 64 at the $2^{\text {nd }}$ week after the primary immunization while post boostering it increased to 132 at the $1^{\text {st }}$ week, 141 at the $2^{\text {nd }}$ week and 178 at the $3^{\text {rd }}$ week post boostering. After challenge, a decrease occurred at the $1^{\text {st }}$ week as it reached 125 then increased to 170 at the $2^{\text {nd }}$ week and 180 at the $3^{\text {rd }}$ week and 185 at the $4^{\text {th }}$ week post challenge (Table 5). On the other hand, the antibody titer in sera of unvaccinated chicks was zero. Moreover, an abrupt increase of antibody titer was recorded, where the antibody titer was 65 at the $4^{\text {th }}$ week of challenge (Table 5).

\section{DISCUSSION}

Salmonellae are responsible for considerable losses in the poultry industry through the death of birds and loss in production and it is estimated to cost poultry farmers in some countries like the United States of America up to 114 million US\$ annually (O’Brien, 1988). In terms of the loss to producers annually, it is difficult to estimate, however any strategies which reduce the incidence of salmonellosis in

Table (1): Protective Efficacy of Salmonella Kentucky inactivated vaccine in SPF chicks challenged with virulent Salmonella Kentucky strain.

*Protection $\%=($ Survival birds/ total number of birds $) \mathrm{X} 100$

Table (2): Results of fecal shedding of Salmonella Kentucky from chicks after challenge

\begin{tabular}{ccccc}
\hline \multirow{2}{*}{ Chicken groups } & \multicolumn{3}{c}{ No. of birds positive for isolation / total No. of living birds } \\
\cline { 2 - 5 } & $1^{\text {st }}$ week & $2^{\text {nd }}$ week & $3^{\text {rd }}$ week & $4^{\text {th }}$ week \\
\hline $\begin{array}{c}\text { vaccinated group } \\
\text { Control non }\end{array}$ & $11 / 53(20.75 \%)$ & $6 / 48(12.5 \%)$ & $4 / 48(8.33 \%)$ & $0 / 48(0 \%)$ \\
vaccinated group & $17 / 24(70.8 \%)$ & $5 / 10(50 \%)$ & $2 / 8(25 \%)$ & $1 / 6(16.66 \%)$ \\
\hline
\end{tabular}


Table (3): Re-isolation of Salmonella Kentucky from vaccinated chickens survived following challenge

\begin{tabular}{lccccc}
\hline \multirow{2}{*}{ Chickens groups } & \multicolumn{3}{c}{ No. of birds positive for isolation / Total No. of } & \multirow{2}{*}{$\begin{array}{c}\text { Higher \% of } \\
\text { re-isolation }\end{array}$} \\
\cline { 2 - 5 } & Heart blood & Liver & spleen & ceca & \\
\hline \multirow{2}{*}{ vaccinated group } & $0 / 48$ & $0 / 48$ & $0 / 48$ & $9 / 48$ & \multirow{2}{*}{$18.75 \%$} \\
Control non & $(0 \%)$ & $(0 \%)$ & $(0 \%)$ & $(18.75 \%)$ & \\
vaccinated group & $9 / 12$ & $7 / 12$ & $7 / 12$ & $9 / 12$ & $75 \%$ \\
\hline
\end{tabular}

Table (4): Results of ELISA for measurement of antibody against Salmonella Kentucky in sera of vaccinated chicks

\begin{tabular}{|c|c|c|c|c|c|c|c|c|c|c|}
\hline \multirow{2}{*}{ Groups } & \multirow{2}{*}{ 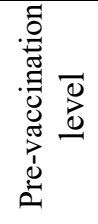 } & \multicolumn{2}{|c|}{$\begin{array}{l}\text { Weeks post } \\
1^{\text {st }} \\
\text { vaccination }\end{array}$} & \multicolumn{3}{|c|}{ Weeks post boostering } & \multicolumn{4}{|c|}{ Weeks post challenge } \\
\hline & & $\begin{array}{c}1^{\text {st }} \\
\text { week }\end{array}$ & $\begin{array}{c}2^{\text {nd }} \\
\text { Week }\end{array}$ & $\begin{array}{c}1^{\text {st }} \\
\text { week }\end{array}$ & $\begin{array}{c}2^{\text {nd }} \\
\text { week }\end{array}$ & $\begin{array}{c}3^{\text {rd }} \\
\text { week }\end{array}$ & $\begin{array}{c}1^{\text {st }} \\
\text { week }\end{array}$ & $\begin{array}{c}2^{\text {nd }} \\
\text { week }\end{array}$ & $\begin{array}{c}3^{\text {rd }} \\
\text { week }\end{array}$ & $\begin{array}{c}4^{\text {th }} \\
\text { week }\end{array}$ \\
\hline $\begin{array}{l}\text { Vaccinated } \\
\text { group }\end{array}$ & 162.8 & 189.2 & 659.5 & 1085.2 & 1130.2 & 2234.1 & 1630 & 2222.3 & 2249.6 & 2272.1 \\
\hline $\begin{array}{l}\text { Control } \\
\text { non } \\
\text { vaccinated } \\
\text { group }\end{array}$ & 155.3 & 167 & 176 & 180.6 & 193.4 & 206.3 & 774 & 1066 & 895.5 & 891.2 \\
\hline
\end{tabular}

Table (5): Results of Microagglutination for measurement of antibody against Salmonella Kentucky in sera of vaccinated chicks

\begin{tabular}{|c|c|c|c|c|c|c|c|c|c|c|}
\hline \multirow{2}{*}{ Groups } & \multirow{2}{*}{ 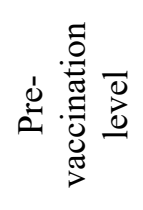 } & \multicolumn{2}{|c|}{$\begin{array}{c}\text { Weeks post } 1^{\text {st }} \\
\text { vaccination }\end{array}$} & \multicolumn{3}{|c|}{$\begin{array}{l}\text { Weeks post } \\
\text { boostering }\end{array}$} & \multicolumn{4}{|c|}{ Weeks post challenge } \\
\hline & & $\begin{array}{c}1^{\text {st }} \\
\text { week }\end{array}$ & $\begin{array}{c}2^{\text {nd }} \\
\text { Week }\end{array}$ & $\begin{array}{c}1^{\text {st }} \\
\text { week }\end{array}$ & $\begin{array}{c}2^{\text {nd }} \\
\text { week }\end{array}$ & $\begin{array}{c}3^{\text {rd }} \\
\text { week }\end{array}$ & $\begin{array}{c}1^{\text {st }} \\
\text { week }\end{array}$ & $\begin{array}{c}2^{\text {nd }} \\
\text { week }\end{array}$ & $\begin{array}{c}3^{\text {rd }} \\
\text { week }\end{array}$ & $\begin{array}{c}4^{\text {th }} \\
\text { week }\end{array}$ \\
\hline $\begin{array}{l}\text { Vaccinated } \\
\text { group }\end{array}$ & 0 & 43 & 64 & 132 & 141 & 178 & 125 & 170 & 180 & 185 \\
\hline $\begin{array}{l}\text { Control non } \\
\text { vaccinated } \\
\text { group }\end{array}$ & 0 & 0 & 0 & 0 & 0 & 0 & 35 & 70 & 65 & 65 \\
\hline
\end{tabular}

poultry are clearly important to all facts of the industry. Reducing Salmonella incidence has become monitored and regulated by Food Safety and Inspection Service (Helmick et al., 1994). Perales and Audicana (1988) reported that the number of Salmonella infected poultry flocks and human beings has been increased substantially in several countries. Although more than 2000 Salmonella serovars have been identified worldwide, only about a dozen serovars accounting for more than 
$65 \%$ of the isolates reported from human beings and poultry (Nagraja et al., 1991). For this reason, considerable efforts have been made to develop Salmonella vaccine, which would induce protective immunity in chickens and reduce the public health hazards (EFSA, 2006). EFSA (2010) reported that the most frequently isolated Salmonella serovars in broiler chickens were, respectively in decreasing order, $S$. Infantis $(29.2 \%$ of the Salmonella positive broiler carcass samples), $S$. Enteritidis $(13.6 \%), S$. Kentucky (6.2\%) and $S$. Typhimurium (4.4\%).

Evaluation of the protective value of a locally prepared inactivated Salmonella Kentucky vaccine was performed by applying the challenge test according to Paiva et al. (2009). This test is considered the master test for determination of the protective value of a vaccine (Timms et al., 1990). The protective value against virulent Salmonella Kentucky; post oral challenge, in chickens vaccinated with the prepared vaccine was $80 \%$. The achieved protection value by the prepared vaccine is accepted to pass the vaccine for use according to Heddleston (1975) and Egyptian Veterinary Codex- CLEVB (2009). Fecal shedding of Salmonella organisms in the vaccinated group of chickens reached $8.33 \%$ while the unvaccinated control group at 3-week post challenge revealed fecal shedding of $25 \%$. No shedding detected at the fourth week post challenge in vaccinated group, while there was $16.6 \%$ shedding in control unvaccinated group. Similar fecal shedding rates were reported by Sayed (2010) and Ibrahim (2014). Salmonella Kentucky was only isolated from ceca of the vaccinated group $(18.75 \%)$, on the other hand in the control non vaccinated group Salmonella Kentucky was re-isolated from heart blood, liver, spleen and ceca with the higher percent isolated from ceca and heart blood (75\%). The ELISA antibody titer in sera of vaccinated chicks was increased from 162.8 pre-vaccination level to 189.2 at the $1^{\text {st }}$ week and 659.5 at the $2^{\text {nd }}$ week after the primary immunization while post boostering it increased to 1085.2 at the $1^{\text {st }}$ week, 1130.2 at the $2^{\text {nd }}$ week and 2234.1 at the $3^{\text {rd }}$ week post boostering. After challenge a decrease occurred at the $1^{\text {st }}$ week as it reached 1630 then increased to 2222.3 at the $2^{\text {nd }}$ week and 2249.6 at the $3^{\text {rd }}$ week post challenge (Table 4). On the other hand, The ELISA antibody titer in sera of unvaccinated chicks was 155.3. Moreover, an abrupt increase of antibody titer was recorded, where the antibody titer was $895.53^{\text {rd }}$ week of challenge (Table 4). These results agree with those obtained by Okamura et al. (2007) and El-Enbaawy et al., (2013). The antibody titer in sera of vaccinated chicks by microagglutination test was increased from zero prevaccination level to 43 at the $1^{\text {st }}$ week and 64 at the $2^{\text {nd }}$ week after the primary immunization while post boostering it increased to 132 at the $1^{\text {st }}$ week, 141 at the $2^{\text {nd }}$ week and 178 at the $3^{\text {rd }}$ week post boostering. After challenge an decrease occurred at the $1^{\text {st }}$ week as it reached 125 then increased to 170 at the $2^{\text {nd }}$ week and 180 at the $3^{\text {rd }}$ week and 185 at the $4^{\text {th }}$ week post challenge (Table 5). On the other hand, the antibody titer in sera of unvaccinated chicks was zero. Moreover, an abrupt increase of antibody titer was recorded, where the antibody titer was 65 at the $4^{\text {th }}$ week of challenge (Table 5). These results agree with those obtained by Abd El-Ghany et al. (2012) and Ibrahim (2014). In Conclusion: killed vaccine of a locally isolated Salmonella Kentucky gave 80\% protection by challenge test in SPF chicks with decreased fecal shedding rate.

\section{REFERENCES}

Abd El-Ghany, Wafaa A., El-Shafii, Soumaya S.A., Hatem, M.E., Dawood, Rehab E. 2012. A Trial to Prevent Salmonella Enteritidis Infection in Broiler Chickens Using Autogenous Bacterin Compared with Probiotic Preparation. J. Agri. Sci., 4(5):91-108. 
Arnon, R.M., shapira, M., Jacob, C.O. 1983. Synthetic vaccines. J. immunol. Methods, 61:261- 273.

Barbour, E.K., Frerichs, W.M., Nabbut, N.H., Poss, P.O., Brinton M.K. 1993. Evaluation of bacterins containing three predominant phage types of Salmonella enteritidis for prevention of infectionin egg-laying chicken. Am. J. Vet. Res., 54(8):488-491.

Brown, SL, Klin, FT, Jones, WL. 1981. Safranin"O" stained antigen microagglutination test for detection of Brucella antibodies. J. Clin. Microbiol. 13:398-400.

Charles, S.D., Hussein, I., Nagraja, K.V., Sivanadan,V. 1994. Adjuvanted subunit vaccines for the control of Salmonella enteritidis infection in turkeys. Am. J. Vet. Res., 55(5):636642.

Cruickshank, R.D, Duguid, J.P., Mermion, B.R., Swain R.H. 1975. Medical Microbiology, $2^{\text {nd }}$ volume, $12^{\text {th }}$ ed. Livingstone, Edinburgh, London and New York.

European Food Safety Authority (EFSA) 2006. Analysis of the baseline study on the prevalence of Salmonella in laying hen flocks of Gallus gallus. EFSA J. 81:1-71.

European Food Safety Authority (EFSA) 2010. Analysis of the base line survey on the prevalence of Campylobacter in broiler batches and of Campylobacter and Salmonella on broiler carcasses in the EU, 2008Part A: Campylobacter and Salmonella prevalence estimates. EFSA J. 8(1403:1503).

Egyptian Veterinary Codex CLEVB 2009. Testing for Extraneous Agents, pp. 111.

El-Enbaawy, Mona I., Ahmed, Zakia A.M., Sadek, M.A., Ibrahim, H.M. 2013. Protective Efficacy of Salmonella Local Strains Representing Groups B, C, D and E in a Prepared Polyvalent Formalin Inactivated Oil Adjuvant
Vaccine in Layers. Inter. J. of Microbiological Res. 4(3):288-295.

Gast, R.K. 2007. Serotype-specific and serotype-independent strategies for preharvest control of food-borne Salmonella in poultry. Avian Dis 51: 817-828.

Grimont, P.A.D., Weill F. X. 2007. Antigenic Formulae of the Salmonella Serovars (9th edition). WHO Collaborating Centre for Reference and Research on Salmonella. Institut Pasteur, Paris, France. Available: http://www. pasteur.fr/ip/portal/action/Webdrive ActionEvent/oid/01s-000036-089.

Haider, M.G., Rahman, M.M., Hossain, M.M., Rashid, M., Sufian, M.A., Islam, M.M., Haque, A.F.M.H. 2007. Production of formalin killed fowl typhoid vaccine using local isolates Salmonella Gallinarium in Bangladesh. Bangl. J. Vet. Med., 5: 33-38.

Heddleston, KL. 1975. Pasteurellosis: Isolation and identification of avian pathogens. Am. Assoc. Avian Patho. pp. 38-51.

Helmick, C.G., Griffin, P.M., Addiss, D.G., Tauxe, R.V., Juranek, D.D. 1994. Infectious diarrheas. In: Digestive Diseases in the United States: Epidemiology and Impact. Ed., Everhart, J. E. Diane Publ. Co., Washington, DC. pp: 85-123.

Hofstad, M.S., Calnek, B.U., Heimboldts, G.F., Ried, M.W., Yoder, H.W. 1997. Diseases of Poultry. $10^{\text {th }}$ Ed. State Univ. Press, Ames Iowa, USA.

Ibrahim, H.M. 2014. Immunological studies on polyvalent Salmonella vaccines. $\mathrm{PhD}$. Thesis (Bacteriology, Immunology and Mycology), Cairo Univ., Fac. Vet. Med.

Liu,W., Yang, Y., Chung, N., Kwang, J. 2001. Induced of humeral immune response and protective immunity in chickens against Salmonella enteritidis after a single dose of killed 
bacterium-loaded microspheres. Avian Dis., 45(4):797-806.

Nagraja, K.V., Kumer, M.C., Pomeroy, B.S. 1991. Is vaccination a feasible approach for control of Salmonella? Proceeding Conference colonization control of human bacterial entropathogenic in poultry, 243-256.

Nourhan, N. Mohammed, Sadek, M.A., Wafaa, R. Abdel Aziz 2014. Studies on pathogenecity of Salmonella enterica serovar Kentucky in chicken.Egypt. J. Comp. Path. Clin. Path., 27(1):18-25.

O'Brien, D.P.J. 1988. Salmonella Enteritidis infection in broiler chickens. Vet. Rec. 122: 214.

Office International des Epizooties (OIE) 2008. Salmonellosis in Manual of diagnostic tests and vaccines for Terrestrial animals.

Office International des Epizooties (OIE) 2012. Salmonellosis in Manual of diagnostic tests and vaccines for Terrestrial animals.

Okamura, M., Tachizaki, H., Kubo, T., Kikuchi, S., Suzuki, A., Takehara, K., Nakamura, M. 2007. Comparative evaluation of a bivalent killed Salmonella vaccine to prevent egg contamination with Salmonella serovars Enteritidis, Typhimurium and Gallinarum biover Pullorum, using 4 different challenge models. Vac. 25:4837-4844.

Paiva, J.B., Penha, F.R.A.C., Arguello, Y.M.S., Silva, M.D., Gardin, Y., Resende, F., Berchieri, J.A., Sesti, L. 2009. Efficacy of several Salmonella vaccination programs against experimental challenge with Salmonella Gallinarum in commercial brown layer and broiler breeder hens. Brazil. J. Poult. Sci. 11: 65-72.

Perales, I., Audicana, A. 1988. Detection of antibodies to Salmonella Enteritidis in sera and yolksfrom experimentally and naturally infected chickens. Lancet. 2:1133-1136.

Sayed, R.H. 2010. Preparation and evaluation of combined inactivated vaccine against Salmonella Enteritidis, Salmonella Typhimurium and Clostridium perfringens type A and $\mathrm{C}$ Toxins in Chickens, MVSc., Thesis (Bacteriology), Fac. Vet. Med. Cairo Univ. Egypt.

Task Force on Zoonosis Data Collection (TFZDC) 2007. Report of Task Force on Zoonosis Data Collection on the analysis of the base line study on the prevalence of salmonella in holdings of laying hen flocks of Gallus gallus.

Tietjen, M., Fungdy 1995. Salmonella and food safety. Crit. Rev. Microbiol., 211:53-83.

Timms, L.M., Marshal, R.N., Breslin, M.F. 1990. Laboratory assessment of protection given by an experimental Salmonella Enteritidis PT4 inactivated, adjuvanted vaccine.Vet. Rec. 127:22-29.

Turki, Y., Ouzari, H., Mehri, I., Ben Aissa, R., Hassen, A. 2012. Biofilm formation, virulence gene and multidrug resistance in Salmonella Kentucky isolated in Tunisia. Food Research International, 45: 940-946

Van Duijkeren, E., Wannet, W.J.B., Houwers, D., Van Pelt, W. 2004. Serotype and phage type distribution of Salmonella strains isolated from humans, cattle, pigs and chickens in the Netherlands from 1984 to 2001. J. Clin. Microbiol., 40:3980-3985. 